\title{
Interesting faunistic records of meniscus midges (Diptera: Dixidae) from Slovakia
}

Jozef Oboňa, Peter Manko, Zuzana Matúšová, Milan Novikmec \& Marek Svitok

Interesting faunistic records of meniscus midges (Diptera: Dixidae) from Slovakia. - Acta Mus. Siles. Sci. Natur., 64: 11-16, 2015.

\begin{abstract}
Records of meniscus midges (Diptera: Dixidae) are reported from lotic and lentic water bodies with of Slovakia. Midges were sampled during specifically aimed research of ponds (project BIOPOND) or during field works related to various studies of running waters. In total, occurrence of 3 species of genus Dixa and 1 species of genus Dixella are presented and shortly discussed. Record of Dixa dilatata Strobl, 1900 on the basis of adult specimen is reported from Slovakia for the first time.
\end{abstract}

Key words: Diptera, Dixidae, Dixa dilatata, faunistics, Slovakia

\section{Introduction}

Dixidae is relatively small Diptera family, characterized by wing venation with 2 forks (Fig. 1) with 32 species in Europe (Wagner 2014). The larvae of this family are aquatic, living in lotic (genus Dixa) or lentic waters (genus Dixella). The adults are usually found near the larval habitat. Meniscus midges, in general, were only scarcely studied in Slovakia. Except immature Dixidae, adults were studied only in Bukovské vrchy (Martinovský 1995), Pol'ana (Ševčík 2009), Gemer (Ševčík 2011) and recently in Muránska planina National park (Ševčík et al. 2013). Only 10 species are recently known from Slovakia (Ševčík \& Halgoš 2009), however occurrence of some species is documented only by larvae material.

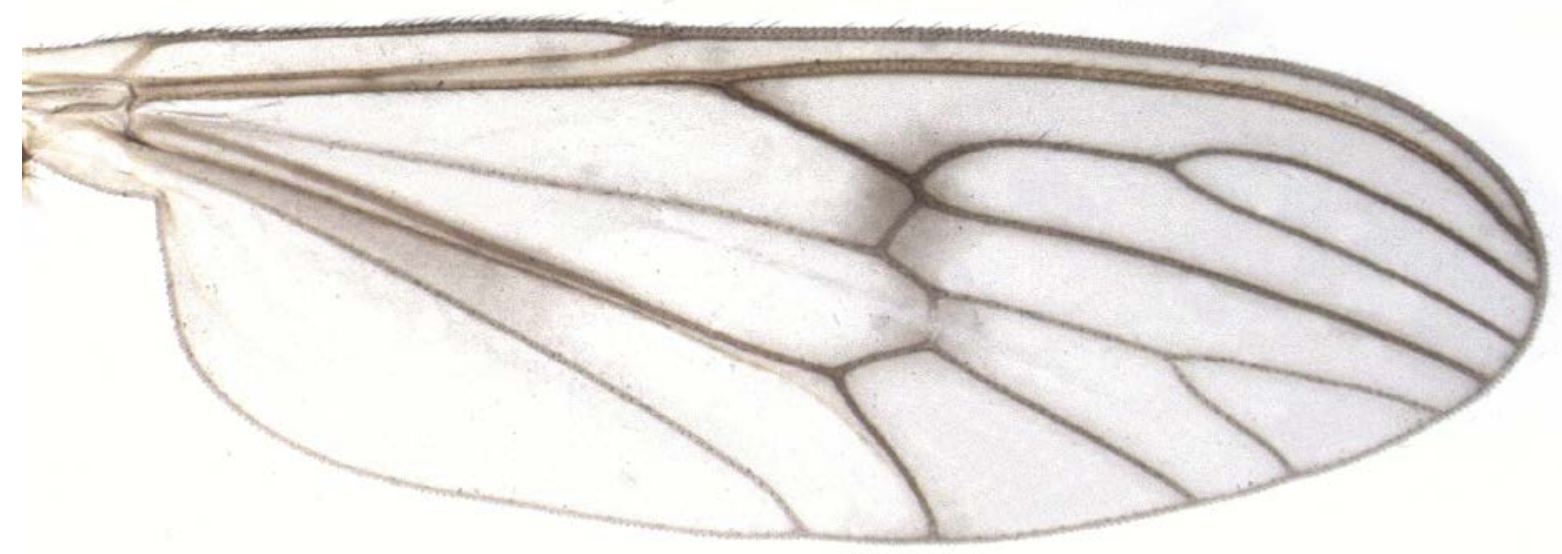

Fig. 1: Wing venation of family Dixidae

\section{Material and methods}

Material was collected by sweep netting on 9 localities and preserved in 75\% ethanol in field. In laboratory, all the individuals were slide mounted and identified using microscope (magnification 50x 200x). All the material is deposited in the Laboratory and Museum of Evolutionary Ecology, Department of Ecology, University of Prešov. Identification and nomenclature were based on Disney (1991) and Ševčík \& Halgoš (2009). 


\section{List of sampling sites (all in Slovakia)}

Site 1: Borkút, Haniska, 48 57' 37.07" N, 21 13' 59.01" E, 240 m a.s.l. (Fig. 2)

Site 2: Čertové diery, $49^{\circ} 1^{\prime} 13.94^{\prime \prime}$ N, 20 51' 20.54" E, 810 m a.s.l. (Fig. 3)

Site 3: Olavec, $48^{\circ} 45^{\prime} 9.04^{\prime \prime} \mathrm{N}, 18^{\circ} 29^{\prime} 25.20^{\prime \prime}$ E, $276 \mathrm{~m}$ a.s.l.

Site 4: Podbanské, 4908' 16.5" N, $19^{\circ} 53^{\prime}$ 50.2" E, 913 m a.s.l.

Site 5: Pod Pekliskom, 48 59' 52.35" N, 2053' 8.51" E, 650 m a.s.l.

Site 6: Pusté Pole, 48 53’14.7" N, 20 14’ 08.4" E, 920 m a.s.l. (Fig. 4)

Site 7: Studený potok brook, 49 $15^{\prime} 18.01^{\prime \prime}$ N, 19 41' 4.49" E, 950 m a.s.l.

Site 8: Trstenec, $48^{\circ} 44^{\prime} 20.32^{\prime \prime} \mathrm{N}, 18^{\circ} 28^{\prime} 54.27^{\prime \prime} \mathrm{E}, 285 \mathrm{~m}$ a.s.l.

Site 9: Železná Breznica, 48 38' 25.86" N, 19 1' 39.99" E, 650 m a.s.l.
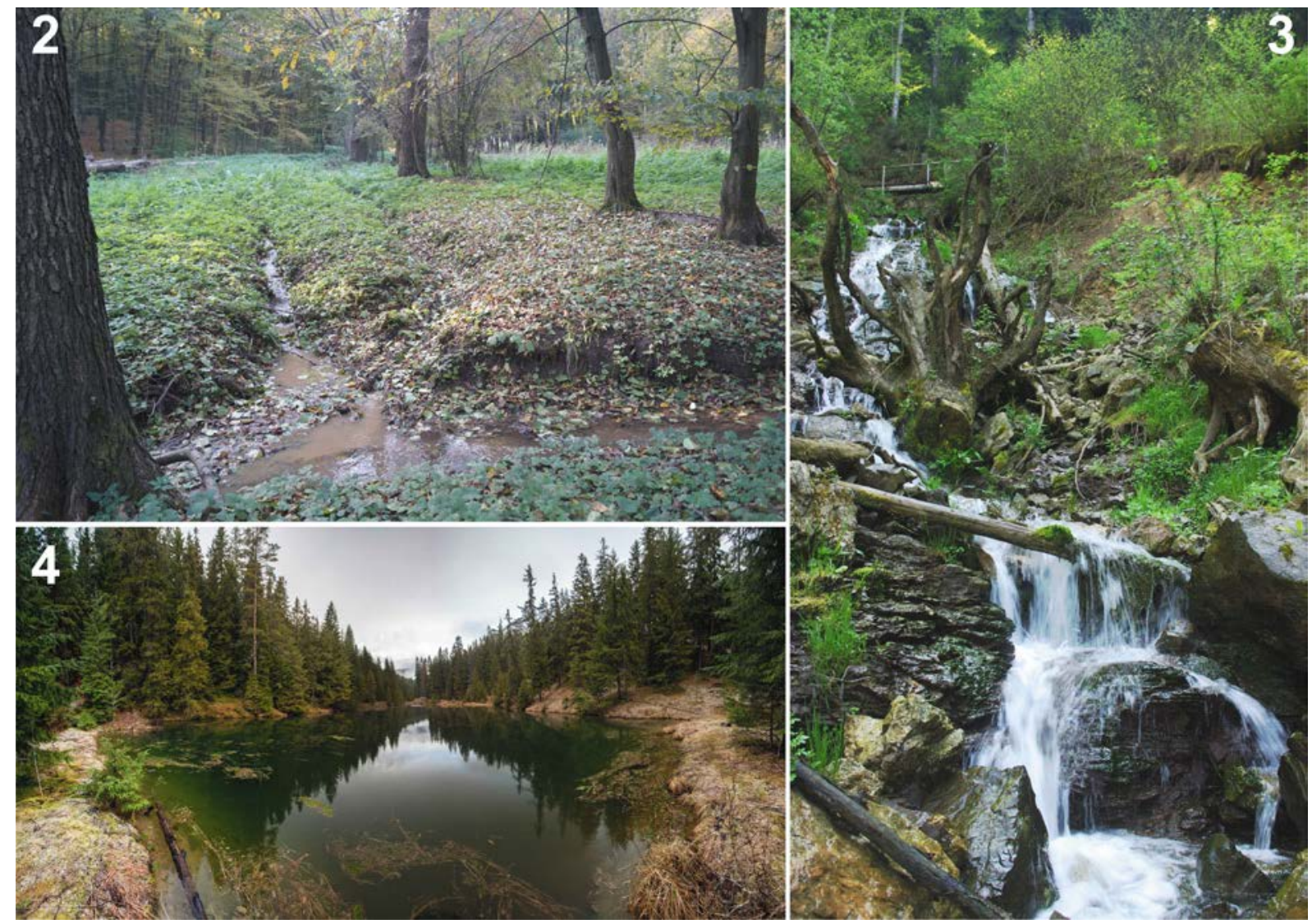

Figs 2-4: Sampling sites. 2 - Borkút, Haniska, habitat of Dixa dilatata Strobl, 1900. 3 - Čertové diery, habitat of Dixa puberula Loew, 1849. 4 - Pusté Pole, habitat of Dixella aestivalis (Meigen, 1818).

\section{Results}

\section{Dixa}

Dixa puberula Loew, 1849

Published records: Ševčík (2009, 2011).

Material examined: Vysoké Tatry Mts., site 7, brook, 28.x.2012, 1M (Fig. 5); Levočské vrchy Mts., site 2, brook, waterfall, 2.v.2014, 1M; site 5, 2.v.2014, $2 \mathrm{M}$.

European distribution: Andorra, Austria, Belgium, Corsica, Czech Republic, Denmark, Finland, France, Germany, Greek, Great Britain, Hungary, Ireland, Italy, Poland, Romania, Sicily, Slovakia, Switzerland, the Netherlands (Ševčík \& Halgoš 2009; Salmela et al. 2014; Wagner 2014). 
Comments: Probably common species, often occurring along mountain streams. Immature stages inhabit stony torrent streams and small stony rivers (Disney 1999).

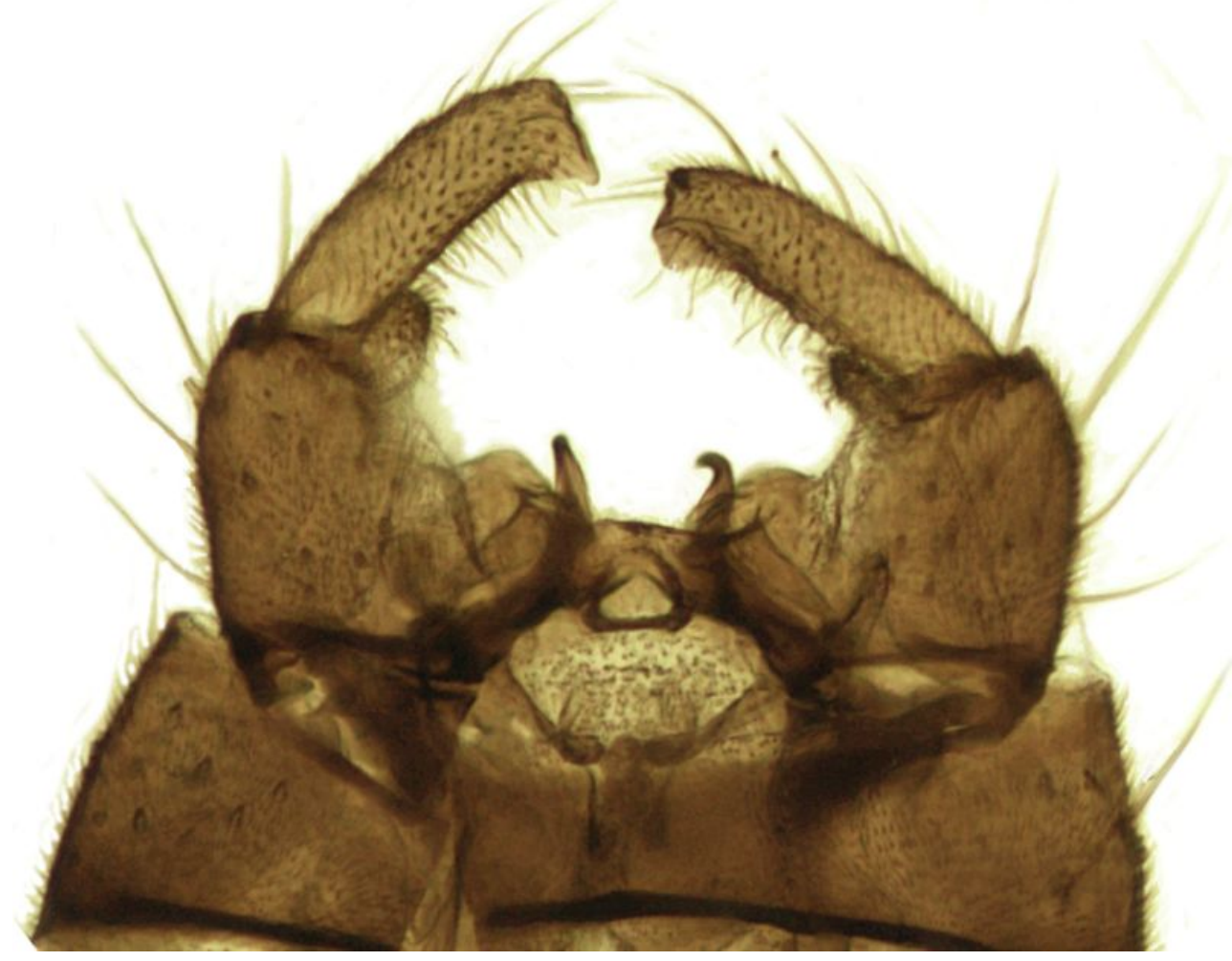

Fig. 5: Male terminalia of Dixa puberula Loew, 1849

Dixa dilatata Strobl, 1900

Material examined: Košická kotlina basin, site 1, spring area, brook, 1.v.2014, 1M (Fig. 6).

European distribution: Belgium, Czech Republic, Denmark, Finland, France, Germany, Great Britain, Ireland, Italy, Poland, Selvagens, Spain, Slovakia, the Netherlands (Ševčík \& Halgoš 2009; Salmela et al. 2014; Wagner 2014).

Comments: A rare European species. Immature stages inhabit spring areas and small streams with emergent stones, rushes, sedges or dead leaves and the margins of larges streams (Disney 1999). Until now, species was known from Slovakia only on the basis of larvae identifications (e.g. Bitušík 1995; Novikmec et al. 2007). Our material represents first adult record of this species from Slovakia.

Dixa submaculata Edwards, 1920

Published records: Martinovský (1995); Ševčík (2009, 2011).

Material examined: Kremnické vrchy Mts., Site 9, brook, 20.iv.2013, 2M; Strážovské vrchy Mts., spring area, Site 8, 9.iii.2014, 1M (Fig.7); 13.v.2014, 3M; Site 3, spring area, 12.v.2014, 1M.

European distribution: Belgium, Corsica, Czech Republic, Denmark, Finland, France, Germany, Greek, Hungary, Ireland, Italy, Lithuania, Poland, Romania, Slovakia, Spain, Switzerland, the Netherlands (Ševčík \& Halgoš 2009; Salmela et al. 2014; Wagner 2014).

Comments: Probably common and widespread species. Immature stages inhabit emergent stones and dead leaves in shallow streams or slow-flowing woodland streams (Disney 1999). 


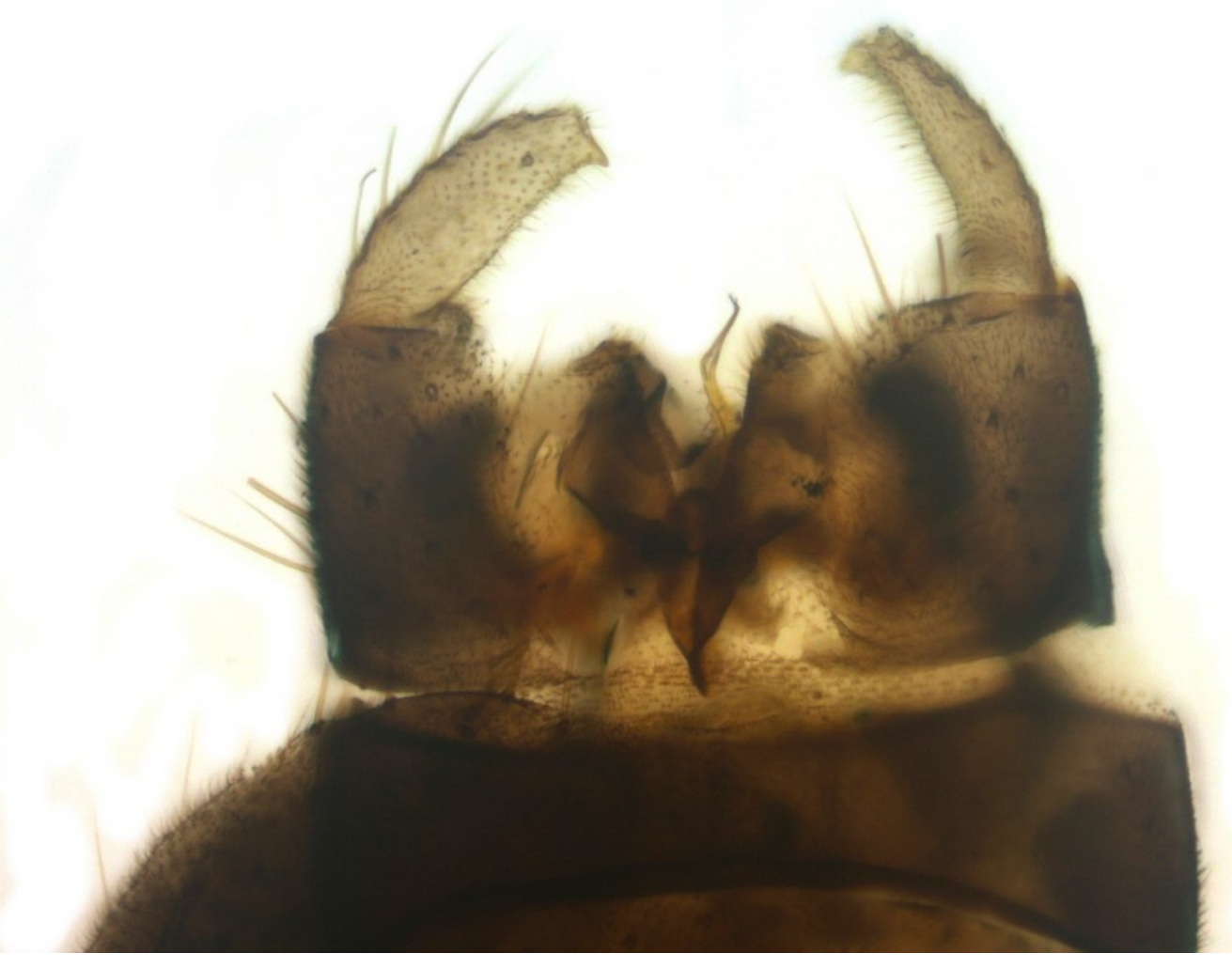

Fig. 6: Male terminalia of Dixa dilatata Strobl, 1900

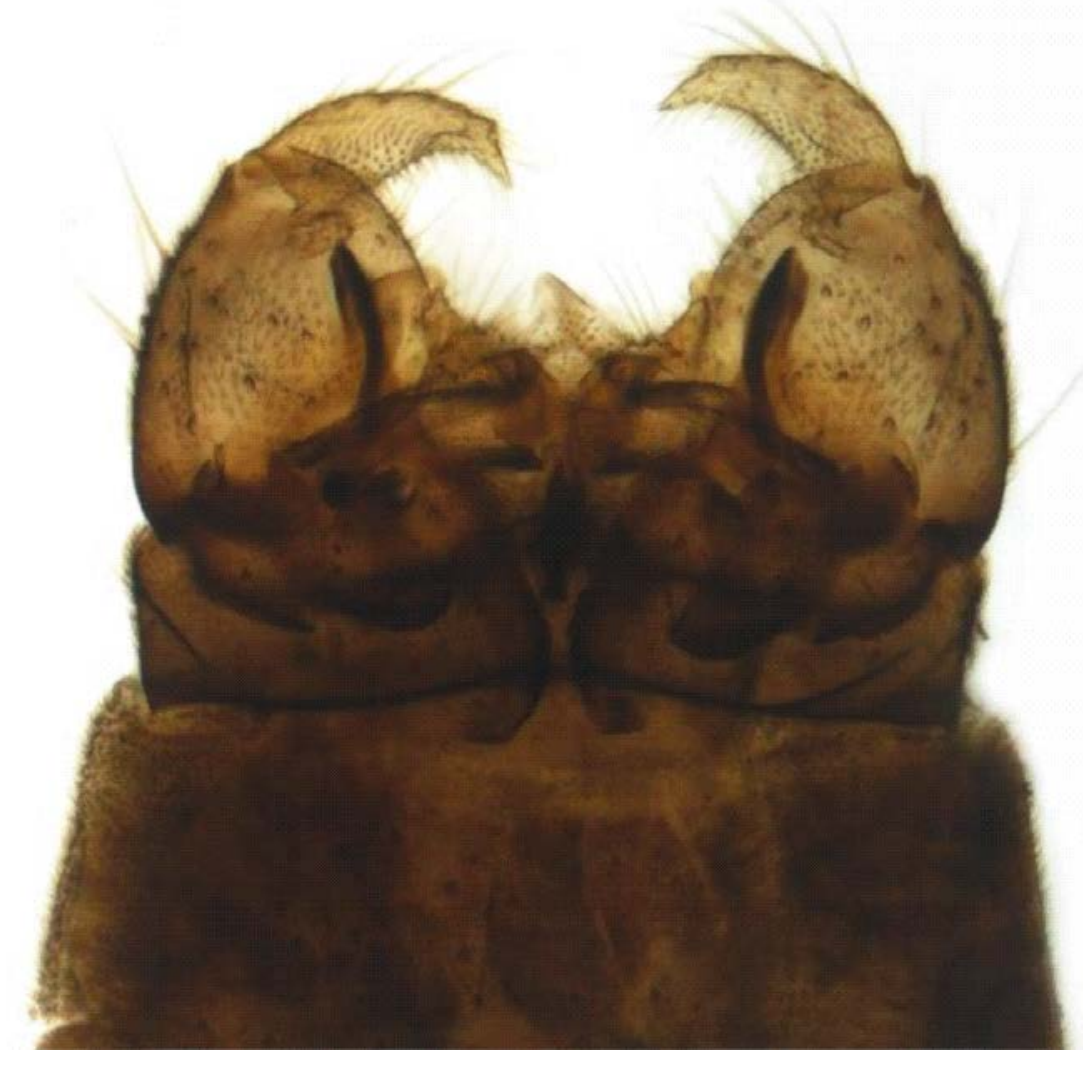

Fig. 7: Male terminalia of Dixa submaculata Edwards, 1920 


\section{Dixella}

Dixella aestivalis (Meigen, 1818)

Published records: Ševčík (2007, 2009).

Material examined: Liptovská kotlina basin, Site 4, pond, 15.vii.2013, 1M (Fig. 8); Čergov Mts., Site 6, pond, 15.vii.2013, 1M.

European distribution: Austria, Belgium, Czech Republic, Denmark, Finland, France, Great Britain, Germany, Greek, Hungary, Ireland, Italy, Lithuania, Norway, Poland, Russia, Slovakia, Spain, Sweden, Switzerland, the Netherlands (Ševčík 2009; Wagner 2014).

Comments: A relatively rare European species. Immature stages inhabit emergent vegetation in variety of ponds and river margins, especially in euthropic waters (Disney 1999).

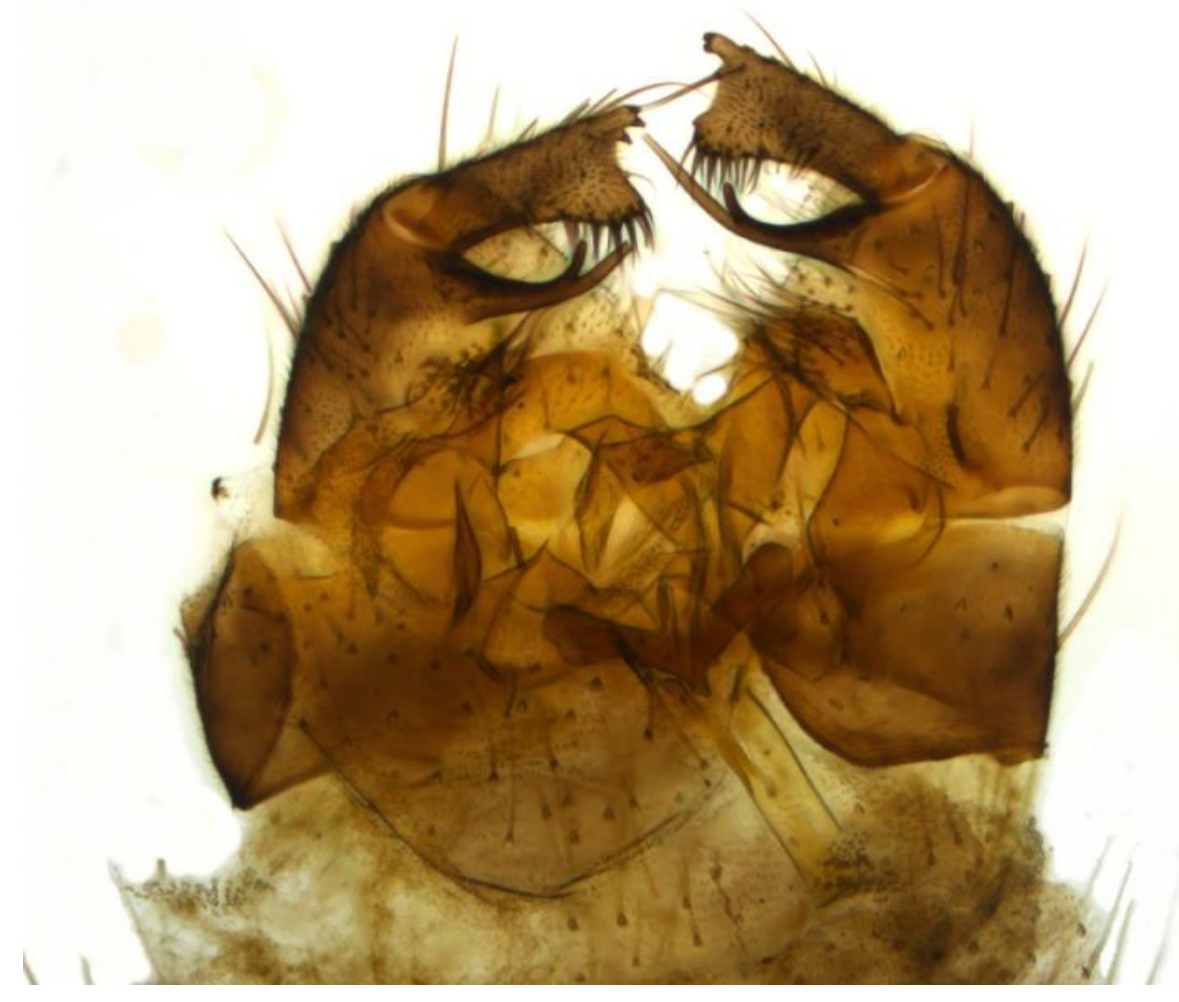

Fig. 8: Male terminalia of Dixella aestivalis (Meigen, 1818)

\section{Discussion}

As already indicated, the investigation of meniscus midges in Slovakia is still far from finished. Few species (e.g. Dixa maculata Meigen, 1818, Dixella amphibia (De Geer, 1776)) that are known from Czech Republic are missing in Slovak checklist (Ševčík \& Halgoš 2009). We suppose that these species occur also in territory of Slovakia. Some species are reported from Slovakia only on the basis of larvae identification (e.g. Dixa nubilipennis Curtis, 1832, Dixella autumnalis (Meigen, 1838) and Dixella serotina (Meigen, 1818) (e.g. Bitušík 1995; Bulánková \& Halgoš 1999; Halgoš \& Bulánková 2003). However, because of uncertainties of larvae identification (Wagner 2004), they occurrence needs to be confirmed by records of adult specimens. 
Acknowledgements: Authors thank Jan Ševčík (Department of Biology and Ecology, University of Ostrava, Czech Republic) for useful suggestions and consultation. This work was supported by the Slovak Research and Development Agency under the contract No. APVV-0059-11, this study was also partialy funded by projects ITMS 26110230119, ITMS 26220120041, ITMS 26220120023 and project KEGA-012PU-4/201203-23.

\section{References}

Bitušík P. (1995): Výsledky prieskumu niektorých vodných biotopov v CHKO Kysuce. In: Korňan J. (ed.): XXVI. Stredoslovenský tábor ochrancov prírody Kysuce. Slovenský zväz ochrancov prírody a krajiny, pp. 21-30.

Bulánková E. \& Halgoš J. (1999): New data on the distribution of Dixidae (Diptera) in Slovakia. In: Jedlička L. (ed.): Dipterologica Bohemoslovaca, Vol. 9. Slovak Entomological Society, Bratislava, pp. 25-29.

Disney R.H.L. (1999): British Dixidae (meniscus midges) and Thaumaleidae (trickle midges): keys with ecological notes. Freshwater Biological Association Scientific Publication No. 56, 129 pp.

Halgoš J. \& Bulánková E. (2003): First record of the species of the genus Dixella Dyar \& Shannon, 1924 (Dixidae, Diptera) from Slovakia. - Biologia, Bratislava, 58: 178.

Martinovský J. (1995): Dixidae, p. 43. In: Roháček J., Starý J., Martinovský J. \& Vála M. (eds): Diptera Bukovských vrchov. Diptera of the Bukovské hills. Humenné, 232 pp.

Novikmec M., Svitok M., Bulánková E., Čiamporová-Zat'ovičová Z., Derka T., Halgoš J., Hamerlík L., Illéšová D., Illyová M., Krno I., Lukáš J., Némethová D., Pastuchová Z., Stašiov S., Šporka F., Štefková E, Tirjaková E., Tomajka J. \& Bitušík P. (2007): Limnology of streams in the Poloniny National Park (the East Carpathians, Slovakia). Technical University in Zvolen, 69 pp.

Salmela J., Paasivirta L. \& Kvifte G.M. (2014): Checklist of the familes Chaoboridae, Dixidae, Thaumaleidae, Psychodidae and Ptychopteridae (Diptera) of Finland. In: Kahanpää J. \& Salmela J. (eds): Checklist of the Diptera of Finland. - ZooKeys 441: 37-46.

Ševčík J. (2007): Faunistic records from Czech Republic and Slovakia. Dixidae. In: Stloukalová V. (ed.): Dipterologica bohemoslovaca Vol. 14. - Acta Zoologica Universitatis Comenianae 47(2): 253-254.

- (2009): Dixidae p. 99. In: Roháček J. \& Ševčík J. (eds.): Diptera of the Pol'ana Protected Landscape Area Biosphere Reserve (Central Slovakia). Zvolen, 340 pp.

- (2011): Anisopodidae and Dixidae (Diptera) of the Gemer region, with a new record for Slovakia. - C̆as. Slez. Muz. Opava (A) 60: 181-184.

Ševčík J. \& Halgoš J. (2009): Dixidae Schiner, 1868. In: Jedlička L., Kúdela M. \& Stloukalová V. (eds): Checklist of Diptera of the Czech Republic and Slovakia. Electronic version 2. $<$ http://zoology.fns.uniba.sk/diptera2009>. Retrieved 7.11.2014.

Ševčík J., Kaspřák D. \& Mantič M. (2013): New records of nematocerous Diptera from Muránska planina National park (Central Slovakia). - Čas. Slez. Muz. Opava (A) 62: 185-189.

Wagner R. (2004): Insecta: Diptera, Dixidae. In: Yule C.M. \& Yong H.S. (eds), Freshwater Invertebrates of the Malaysian Region, Selangor, Malaysia: Aura Productions, pp. 634-637.

- (2014): Fauna Europaea: Dixidae. In: Beuk P. \& Thomas P. (eds.): Fauna Europaea: Diptera, Nematocera. Fauna Europaea version 2.6, <http://www.faunaeur.org>. Retrieved 7.11.2014.

Authors' addresses: Jozef Oboňa \& Peter Manko: Department of Ecology, Faculty of Humanities and Natural Sciences, University of Prešov, 17. novembra 1, SK-081 16 Prešov, Slovakia; obonaj@centrum.sk,mankope@gmail.com.

Zuzana Matúšová, Milan Novikmec \& Marek Svitok: Department of Biology and General Ecology, Faculty of Ecology and Environmental Sciences, Technical University in Zvolen, T. G. Masaryka 24, SK-960 53 Zvolen, Slovakia; zuzana.matushova@gmail.com,novikmec@tuzvo.sk, svitok@tuzvo.sk. 